\title{
Communication Strategy of Dinas Komunikasi Dan Informatika Daerah Istimewa Yogyakarta in Socializing Jogja Smart Province Program Amongst the Jogjakarta Society
}

\author{
Fitrah Fasyanabilla Lotan', Choirul Fajri ${ }^{2}$ \\ ${ }^{1}$ Communication Department, Universitas Ahmad Dahlan \\ ${ }^{2}$ Communication Department, Universitas Ahmad Dahlan \\ Corresponding Author's Email: choirul.fajri@comm.uad.ac.id
}

\begin{abstract}
This study seeks to analyze communication strategy Dinas Komunikasi dan Informatika Daerah Istimewa Yogyakarta in socializing Jogja Smart Province Program amongst the Jogjakarta Society. The purpose of this study is to obtain an overview of the strategy of Dinas Komunikasi dan Informatika Daerah Istimewa Yogyakarta in socializing Jogja Smart Province Program amongst the Jogjakarta Society. Dinas Komunikasi dan Informatika Daerah Istimewa Yogyakarta held several events related to the socialization of the Jogja Smart Province program. The event was divided into two types, direct socialization (face to face) and indirect socialization. The socialization was immediately carried out by Dinas Komunikasi dan Informatika Daerah Istimewa Yogyakarta by taking the Smart Area "Sumbu Filosofi" as a pilot project. Dinas Komunikasi dan Informatika Daerah Istimewa Yogyakarta held a roadshow to socialize the Smart Area "Sumbu Filosofi" project. Indirect socialization conducted by Dinas Komunikasi dan Informatika Daerah Istimewa Yogyakarta is through socialization in several media. These media include conventional media such as Radio, TV and print media as well as new media or internet. The research method used in this study is descriptive qualitative, with data collection through interviews, observation, and studying official documents. The results in socializing the Jogja Smart Province program by referring to factors such as recognizing communication targets, media selection, assessment of message objectives, and the role of communicators in communication that are already running well but not optimal. Optimization in outreach on social media has not been so intense as well as direct socialization of the Jogja Smart Province program which has not been widely carried out in educational institutions. Nevertheless, the socialization that took the Smart Area "Sumbu Filosofi" as a pilot project has been going well.
\end{abstract}


Keywords: Government Program Socialization, communication strategy, Smart Province Program, Department of Communication and Informatics of DIY

\section{INTRODUCTION}

The internet which has the nature of not knowing space and time will make it easier for humans in the current modern era. Aspects of human life that were originally manual through the Internet will be easier and faster. The following are data reported by the Indonesian Internet Service Providers Association (APJII) regarding internet users in Indonesia by region.

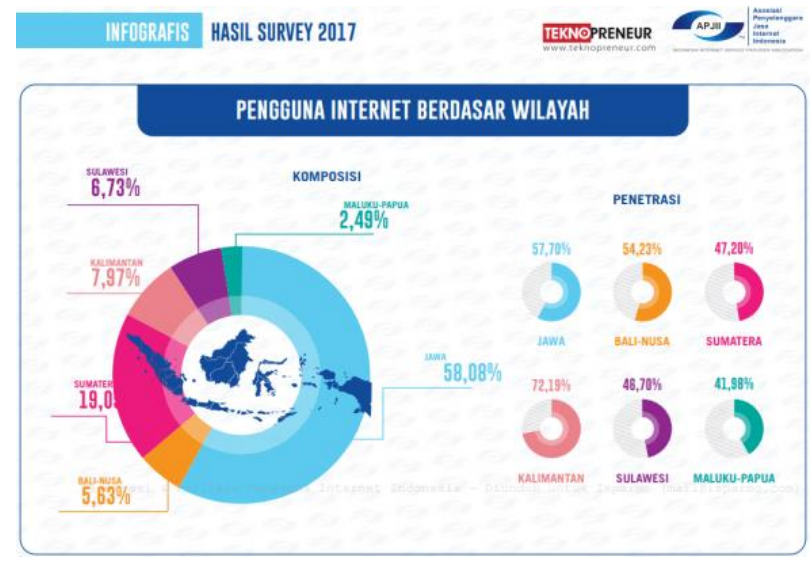

Picture 1 . The Graph of the internet using in Indonesia (sources : http://isparmo.web.id/2018/08/01/data-statistik-pengguna-internet-di-indonesia-2017berdasarkan-survey-apjii/ at 16/4/2019 8:41 WIB

Seeing the growth of the Internet, especially in Java, which is very high compared to other regions in Indonesia, the government implemented a policy in terms of digital-based public services. DIY Government-issued DIY Governor Regulation No. 42 of 2006 concerning Jogja Cyber Province which focused on the development of Digital Government Services (DGS). Jogja Cyber Province then developed into Jogja Smart Province in 2015. The concept of Jogja Smart Province aims to prepare DIY to become a livable city.

In Jogja Smart Province, the government focuses on 7 categories, namely 1) Smart Governance, 2) Smart healthcare, 3) Smart Building, 4) Smart Mobility and Infrastructure, 5) Smart Technology, 6) Smart Energy, 7) Smart Citizen.

DIY Governor Sri Sultan Hamengkubuwono in a seminar on the preparation of the Jogja Smart Province masterplan at Grand Inna Malioboro, Yogyakarta, said that in implementing JSP, an effective cross strategy was needed, referring to the DIY 2017-2022 vision. The cross strategy consists of an economic cross, regional financial cross, and cultural

cross. 
(http://jogja.tribunnews.com/amp/2018/08/14/jogja-smart-province-berpotensisupport pembangunan-berbasis-kilayahan accessed 24 March 2019 at 15:15 WIB)

In the implementation of Jogja Smart Province, it will be run under the Regional Management of the Governor of DIY and agreed by the Regency - City. Sri Sultan Hamengkubuwono also said that such a thing would be the focus of JSP to accommodate cross-regional government services in DIY with district-city governments as the development of Government Digital Services (DGS), which had been horizontal. The Sultan also added that to realize the JSP, multi-stakeholder participation is needed, intelligent society, with equality and good education, sustainable strategic plans, and weighty partnerships.

In its application, the Office of Communication and Informatics DIY simplifies into 5 main pillars in the Jogja Smart Province program, namely: Smart governance, Smart culture, Smart, environment, Smart Living, Smart Society. The aim of the 5 pillars can make people's lives in DIY easier through the use of information technology.

In 2016, the Government of the Special Region of Yogyakarta through the Office of Communication and Information has launched an information provider application called the Special Jogja Application. This application is smartphonebased and can be downloaded for free by smartphone users. This application serves to provide information services to the public about services and information about Jogjakarta more accurately in anticipation of the spread of hoaxes.

On August 25, 2018, the Department of Communication and Information of DIY had inaugurated the Diskominfo Co-working Space (DCS). The purpose of establishing DCS is to facilitate the community and communities in Jogja in developing digital creative industries. The concept of built-in DCS is the concept of disability friendly. In addition to the two things above, DIY Diskominfo also conducted a series of Socialization Workshop to Regency / City on the JSP program that began in Kulonprogo Regency on 13 November 2018, Jogja City on 15 November 2018, Bantul Province on 23 November and ended in Gunungkidul Regency on November 27, 2018.

In this study, the authors wanted to find out the communication strategy carried out by the Yogyakarta Special Region Communication and Information Office in socializing the Jogja Smart Province program to the people in DIY.

\section{LITERATURE REVIEW}

\section{a. Concept of Communications}

Littlejohn \& Foss in Cangara (2014: 35) states that communication cannot be separated from daily activities and is so connected that sometimes humans ignore their spread, interests, and complexity. In everyday life, humans can not be separated from communication activities with others. Humans convey each other 
and receive messages both verbally and non verbally. According to Dan Nimmo in Tabroni (2014: 14) states:

"Communication can also be understood as the re-creation of information ideas by the public if given instructions with main symbols, slogans, or themes. Important characteristics of communication can be defined as two things. First, communication is the process of forming meaning on a particular message that is conveyed to others. Second, the effectiveness of the communication process is very dependent on the process of interpretation of the communicant or the message it receives ".

Communication is the re-creation of information ideas by the public when accompanied by instructions such as a symbol, slogan, or main theme. As explained by Dan Nimmo, in the process of effective communication or not a communication process is highly dependent on the process of interpretation of the communicant or the message it receives. So, in the socialization process, it is very important to consider the contents of the message so that it can be conveyed well to the communicant.

Harold D. Laswell in Fiske (2011: 28) provides an overview in the form of questions about the components of communication, namely Who Says What In What Channel To Whom With What Effect. The question has covered all the basic components of communication. The basic components of communication are the communicant which is the source of information, then the message to be conveyed, the media or channel used by the communicator to deliver the message to the communicant, then the communicant who is the recipient of the information, and the effect which is the response after the message is delivered.

An effective strategy is needed to achieve a goal. Communication strategies according to Mohr and Nevin as the use of a combination of communication facets in which there is a frequency of communication, communication formality, communication content, and communication channels (Kulvisaechana, 2001: 17-18).

In developing a communication strategy, it is very important to consider the supporting factors and inhibiting factors. According to Effendy (2016: 35-39) we must consider the following targets for communication, media, messages, and communicators:

1) Identify Communication Goals

In compiling a communication strategy, knowing and recognizing who will be the target of our communication is very important. So, we can consider and reconstruct the contents of the message that we will convey to the communicant well so that the contents of the message can be conveyed to the communicant as a whole and minimize the reduction of the message content. Recognizing the goals of communication well will be able to help us in achieving the goals rather than communication, whether the 
communication is limited to being known (by informative methods) or that communication can influence the communicant to take a particular action (persuasive or instructive methods). In the communication process, we must also consider the following factors: frame of reference and situation and condition factors.

2) Selection of communication media

The choice of communication media needs to be considered in the delivery of information moreover in mass communication. At present, communication media can be divided into two types of communication media, namely traditional communication media and modern communication media. Traditional or conventional communication media such as newspapers, bulletin boards, posters, banners, magazines, radio, and television. While modern communication media is the internet.

3) Assessment of Communication Message Purposes

The communication process has a specific purpose. This determines the technique that will be used in the process of delivering a message. The technique can be in the form of information technology, persuasion techniques or instruction techniques. In determining the technique of delivering messages, we must also know and understand the contents of the message to be conveyed.

Communication messages consist of the contents of the message and symbols or symbols. In conveying the contents of the message, can use many symbols. Symbols that can be used in conveying the contents of the communication are language, pictures, colors, body language (gesture), and so on. In the modern era like today, the contents of messages are mostly translated through films, songs, or other works of art.

Language is the symbol most widely used in communication. Because language can express and represent thoughts and feelings, language can also describe facts and opinions to be more easily understood.

4) The Role of Communicators in Communication

An effective communication process is also inseparable from the communicator's role in conveying the message. Source attractiveness and source of credibility.

a) Source of Attractiveness

The attractiveness of the source will be able to directly change the attitude, opinion, and communication behavior of the communicant if the communicant feels that the communicator is in the same perception with him. If the communicant has felt the same perception with the communicator, the communicant will be able to obey the contents of the message delivered by the communicator. 
b) Source of Credibility

Successful delivery of messages also depends on the credibility of the source or communicator. The credibility of a communicator will result in confidence in the communicant in receiving the contents of the message conveyed by the communicator. For example, people will have more confidence if a heart health seminar invites cardiologists as speakers rather than general practitioners.

There are 4 (four) objectives in the communication strategy proposed by Wayne Pace, Brant D Peterson, M. Dallas, quoted by Onong Uchjana Effendy (1997: 35), as follows: (1) To Secure Understanding, namely to ensure an understanding in communicating, (2) To Establish Acceptance, i.e. how the acceptance is continuously fostered well, (3) To Motivate Action, namely to motivate an action, (4) To Goals Which Communicator Sought To Achieve, namely how to achieve the goals to be achieved by the communicator of the communication process.

\section{b. Persuasive Communications}

Persuasive communication is a theory often used in socialization. The term Persuasion comes from the Latin, persuasion which means to persuade, invite and seduce. Persuasive communication according to Soemirat \& Suryana (2014: 20) in his book entitled Persuasive Communication says that persuasive communication is communication that aims to influence one's attitudes, opinions, and behavior that can be verbal or nonverbal. In persuasion communication all its components can cause change, it can be done consciously or unconsciously and or verbally and nonverbally.

The elements of persuasive communication include:

1. The sender of the message or persuader, namely the person who sent the message (communicator) to influence the attitudes, opinions, and behavior of the intended person (communicant) both verbally and non-verbally.

2. Message Recipient or Persuadee, that is the person to whom the message is conveyed both verbally and non-verbally

3. Message, that is information that will be conveyed by persuader to persuade. the contents of persuasive messages must be arranged systematically so that the message intends to be on target.

4. Channels are intermediaries between communicators and communicants. Channels are media for delivering messages. The media can be anything by the type of communication carried out.

5. The effect is the response of the communicant to the communicator in the form of external and internal. 
Effects of Persuasive Communication is a change that occurs in the communicant after persuasive communication is done. The effect that can occur in the form of changes in attitudes, opinions, and behavior.

\section{c. Communication Policy Theory}

Communication policy according to Mc Braid in Cangara (2013: 12) are principles. The rules or guidelines for building a communication system so that it becomes a framework for coordinating activities, choosing an approach that is appropriate to the allocation of funds, structural decisions that can affect communication activities, as well as having the goal of eliminating the imbalance of external and internal factors and setting priorities will be taken.

Communication policy has a very broad scope of coverage. In the communication policy, there is a communication plan. Communication planning is arranged systemically which contains medium or short term planning. Every plan must be based on a communication policy guideline, if the plan is not by the communication policy then the efforts in communication planning will be in vain.

\section{METHODOLOGY}

The methodology of this study uses descriptive qualitative methods with a case study approach. this research uses analysis of literature and media. Strauss and Corbin (2003: 4), explained that qualitative research is a type of research whose findings should not be through statistical procedures or other forms of calculation. Research using case studies is research that focuses on one particular object and studies it as a case. data is collected through various sources (Nawawi, 2003:1). Qualitative research requires a sharp and in-depth analysis of various factors associated with the case so that in the end an accurate conclusion will be obtained (Sutedi, 2009: 61). The purpose of this descriptive study with a qualitative approach is to explain the phenomenon deeply, through collecting data and using case study methods. The research flow is done by conducting literature research both online and offline. Then analysis of communication theories related to the case.

\section{RESULTS AND DISCUSSION}

\section{Jogja Smart Province Program}

The Jogja Smart Province (JSP) program is a program that began with the vision and mission of the Yogyakarta Special Region Regional Medium-Term Development Plan (RPJMD) in welcoming the Indian Ocean Century. The function of Jogja Smart Province is to support the strategic issues above to achieve its goals using information technology.

The Yogyakarta Office of Communications and Information Technology simplifies 7 strategic issues contained in the 2017-2022 RPJMD into 5 main pillars. The 5 main pillars are Smart governance, Smart culture, Smart environment, Smart 
Living, and Smart Society. The 5 pillars aim to make the lives of DIY people easier by utilizing information technology.

DISKOMINFO DIY makes framing or concept of socialization that puts forward the values of philosophy and culture typical of the people of DIY which are then united with the use of Information and Communication Technology (ICT). The communication strategy is divided into two, namely the short-term and long-term communication strategies. JSP's short-term socialization strategy will focus more on socialization around the Smart Area philosophy axis. The axis of DIY philosophy is an imaginary line between the krapyak stage and the Jogja monument. The area of this philosophical axis is currently the main target for the socialization of the Jogja Smart Province program. Meanwhile, for the long term, the socialization is expected to reach all provinces of DIY.

Another communication strategy undertaken by Diskominfo DIY in disseminating the Jogja Smart Province program is to introduce the Jogja Special application. It is well known that the Special Jogja Application is one part of the Jogja Smart Province Program. Special Jogja applications that provide digital-based public services are also expected to be a medium for the community to improve their economic level with digital-based marketing.

In this study, researchers used the theory of Communication Strategies according to Effendy (2016: 35-39) which explains that we must consider the goals of communication, media, messages, and communicators in communication strategies.

1) Identifying the audience/communication target

Based on the results of the analysis and findings in the field, in getting to know the communication objectives of the Diskominfo DIY as a communicator, they have sorted and selected the communication targets and classified them in terms of age, background, and residence. According to researchers, this has been going well. For example, to socialize the JSP program to the community with an adult to old age range, socialization is mostly done through direct or face-to-face socialization. So, Diskominfo DIY conducted a roadshow on Smart Area Axis Philosophy.

Meanwhile, the socialization carried out for young people and adolescents is more to the holding of contests. The competition program organized by DIY Diskominfo and at the same time socializing the JSP program include the "Amazing Race Video Competition" which is a vlog making competition with the theme of the Philosophy Axis. Another contest is a blogging contest at the ICT Show. Unfortunately, Diskominfo DIY has not cooperated much with educational institutions such as universities or secondary schools in direct socialization with the target of the younger generation. The researchers felt it was important to invite educational institutions with their students to participate to make the Jogja Smart Province program a success. 
Media Selection

The choice of communication media carried out by Diskominfo DIY in socializing the JSP program is to divide the media according to the type and nature of the media. DIY Diskominfo also choose the communication media by the target or communication target.

Conventional media such as radio, television and print media can reach the adult or old generation while new media can reach the younger generation. JSP socialization conducted on the Internet media, in this case, is social media as we all know that social media is currently very much loved by the public, especially the younger generation.

In this case, Diskominfo DIY has not been so optimal in promoting JSP programs in social media. This is certainly unfortunate because seeing the nature of the internet that interests the public and the internet that does not recognize space and time should be an effective medium for socializing the JSP program. DIY Diskominfo has not made a campaign on social media with the theme of the Sumbu Filosofi. Campaigners in social media researchers thought it would be effective to create a level of public awareness, especially internet users of the Jogja Smart Province program, especially regarding the Sumbu Filosofi.

3) Study the Purpose of Communication Messages

Study the Purpose of the Message. Based on the results of research and analysis that researchers have done, the assessment of the purpose of the message that has been carried out by Diskominfo DIY in socializing the JSP program is good. DIY Diskominfo currently constructs the socialization message into a single unit by its pilot project. The message is about the Smart Area Sumbu Filosofi.

DIY Diskominfo has the purpose of this message is that the people of DIY especially those around the Axis Philosophy area can find out what the philosophy axis is and what it has to do with the JSP program. On various occasions, DIY Diskominfo held competitions that had the theme of Axis Philosophy. Unfortunately, the Special Jogja Application is still not popular among the people. DIY Diskominfo has not done any intensive socialization related to the Jogja Application.

4) The Role of Communicators in Communication

The Role of Communicators in Communication. Based on observations and analyzes conducted by researchers, the selection of communicators in the socialization process carried out by Diskominfo DIY has been going well. This is seen from every information dissemination conducted by Diskominfo DIY, communicators who act as speakers are people who know for certain the JSP program. The communicators are the Head of DIY Communication and Information Agency Ir. Rony Primanto Hari, Chair of 
Commission A DIY DPRD Eko Suwanto S.T, M.Sc and Chairperson of the JSP DIY Drafting Team Ir.Lukito Edi Nugroho, M.Sc, Ph.D. Head of Application and Information Division Drs. Bayu Februarino Putro, Head of Public Service Application Section Dr. Sayuri Egaravanda, S.Kom. the communicators work by their fields. This can foster a sense of trust in the information provided by the communicators so that, the contents of the message can be conveyed intact to the communicant.

\section{CONCLUSION}

Based on the findings and results of the analysis using Onong Uchjana Effendy's Communication Strategy theory which consists of Knowing the communication objectives, Selecting communication media, Assessing the purpose of communication messages, and the role of communicators in communication, the conclusions can be drawn as follows:

First, from the results of the analysis and findings in in the field, in recognizing the communication objectives of Diskominfo DIY as a communicator, it has sorted and selected the communication targets and classified them in terms of age, background, and residence. According to researchers, this has been going well. For example, to socialize the JSP program to the community with an adult to old age range, socialization is mostly done through direct or face-to-face socialization. So, Diskominfo DIY conducted a roadshow on Smart Area Axis Philosophy. Meanwhile, the socialization carried out for young people and adolescents is more to the holding of contests.

Second, the selection of communication media carried out by Diskominfo DIY in socializing the JSP program is to divide the media according to the type and nature of the media. DIY Diskominfo also choose the communication media by the target or communication target. The communication media are divided into 4 (four) including Audio Media (radio), Audio-Visual Media (television), Print Media and New Media (Internet). In this case, Diskominfo DIY has not been so optimal in promoting JSP programs in social media. This is certainly unfortunate because seeing the nature of the internet that interests the public and the internet that does not recognize space and time should be an effective medium for socializing the JSP program. DIY Diskominfo has not made a campaign on social media with the theme of the Axis Philosophy. Campaigners in social media researchers thought it would be effective to create a level of public awareness, especially internet users of the Jogja Smart Province program, especially regarding the Axis of Philosophy.

Third, Study the Purpose of the Message. Based on the results of research and analysis that researchers have done, the assessment of the purpose of the message that has been carried out by Diskominfo DIY in socializing the JSP program is good. DIY Diskominfo currently constructs the socialization message into a single unit by its pilot project. The message is about the Smart Area Axis Philosophy. DIY 
Diskominfo has the purpose of this message is that the people of DIY especially those around the Axis Philosophy area can find out what the philosophy axis is and what it has to do with the JSP program. On various occasions, DIY Diskominfo held competitions that had the theme Axis Philosophy. DIY Diskominfo has the concept of implementing communication-based technology while prioritizing Jogja's philosophy and culture. Unfortunately, the Special Jogja Application is still not popular among the people. DIY Diskominfo has not done any intensive socialization related to the Jogja Application.

Fourth, the role of communicators in communication. Based on observations and analyzes conducted by researchers, the selection of communicators in the socialization process carried out by Diskominfo DIY has been going well. This is seen from every information dissemination conducted by Diskominfo DIY, communicators who act as speakers are people who know for certain the JSP program. The communicators are the Head of DIY Communication and Information Agency Ir. Rony Primanto Hari, Chair of Commission A DIY DPRD Eko Suwanto S.T, M.Sc and Chairperson of the JSP DIY Drafting Team Ir.Lukito Edi Nugroho, M.Sc, Ph.D. Head of Application and Information Division Drs. Bayu Februarino Putro, Head of Public Service Application Section Dr. Sayuri Egaravanda, S.Kom. the communicators work by their fields. This can foster a sense of trust in the information provided by the communicators so that, the contents of the message can be conveyed intact to the communicant.

Concerning the four factors above, the Jogja Smart Province Program socialization should be carried out optimally by Diskominfo DIY. Considering that this JSP program is a large program that includes central pillars that are highly related to the community. The JSP program is a program that is still foreign to some people, therefore, DIY Diskominfo, in this case, is a communicator who must work optimally to be able to introduce this JSP program to the wider community. Hopefully, the Jogja Smart Province program can become a reference for the Smart Province program in various provinces in Indonesia.

\section{REFERENCES}

Book

Cangara, Hafied. (2013). Perencanaan \& Strategi Komunikasi, Depok: PT. Raja Grafindo Persada

Cangara, Hafied. (2014). Perencanaan \& Strategi Komunikasi, Depok: PT. Raja Grafindo Persada

Effendy, Onong Uchjana. (1997). Ilmu Komunikasi Teori dan Praktek. Cetakan kesepuluh, Bandung: $\quad$ Remaja Rosada Karya. 
Effendy, Onong Uchjana. (2016). Ilmu Komunikasi: Teori dan Praktek. Bandung: PT Remaja Rosdakarya. Cetakan ke 27

Fiske, John. (2011). Cultural and Communication Studies. Yogyakarta: Jalasutra.

Kulvisaechana, Somboon. (2001). The Role of Communication Strategies in Change Management Process : A case study of consignia brand and business status introduction. England: University of Cambridge

Nawawi, Hadari. (2003). Manajemen Sumber Daya Manusia untuk Bisnis yang Kompetitif. Yogyakarta: Gadjah Mada Press.

Soemirat, Saleh. Suryana, Asep. (2014). Komunikasi Persuasif. Banten: Universitas Tebuka.

Tabroni, Roni. (2014). Marketing Politik: Media dan Pencitraan di Era Multipartai. Yogyakarta: Graha Ilmu.

\section{Website}

http://isparmo.web.id/2018/08/01/data-statistik-pengguna-internet-di-indonesia-2017berdasarkan- survey-apjii/

http://jogja.tribunnews.com/amp/2018/08/14/jogja-smart-province-berpotensi-support pembangunan-berbasis-kilayahan. 